\title{
Congenital Constriction Band Syndrome: Clinical Study of Three Cases in Togo
}

Foli Agbeko ${ }^{1,2^{*}}$, Fidèle Comlan Dossou ${ }^{3}$, Mawouto Fiawoo ${ }^{1,4}$, Elom Ounoo Takassi ${ }^{1,4}$, Mawulolo Kossi Kato ${ }^{4}$, Mawuse Koffi Guédénon ${ }^{1,4}$, Kokou Agbékogni Réné Segbedji5 ${ }^{5,6}$, Djatougbé Ayaovi Elie Akolly ${ }^{1,4}$, Magnoulelem N'Zonou $^{7}$, Sollim Talboussouma ${ }^{6}$, Mazama Pakoudjare ${ }^{2}$, Homba Daké Batalia ${ }^{3}$, Kokouvi Evenyo Abalo ${ }^{3}$, Edem Koffi Djadou $^{1,3}$, Kokou Nadiedjoa Douti ${ }^{1,2}$, Adama Dodji Gbadoe ${ }^{1,7}$, Yawo Dzayissé Atakouma ${ }^{1,4}$, Didier Koffi Gnamey ${ }^{1,4}$

${ }^{1}$ Département de Pédiatrie / Faculté des Sciences de la Santé, Université de Lomé, Lomé, Togo

${ }^{2} \mathrm{CHU}$ Campus, Service de Pédiatrie, Lomé, Togo

${ }^{3}$ CHR Sokodé, Service de Pédiatrie, Sokodé, Togo

${ }^{4}$ CHU Sylvanus Olympio, Service de Pédiatrie, Lomé, Togo

${ }^{5}$ Département de Pédiatrie / Faculté des Sciences de la Santé, Université de Kara, Kara, Togo

${ }^{6}$ CHU Kara, Service de Pédiatrie, Kara, Togo

${ }^{7}$ Hôpital de Bè, Service de Pédiatrie, Lomé, Togo

Corresponding Author: Dr. Foli Agbeko ${ }^{\text {ORCID iD }}$

Address: 03 BP 30 434, Lomé, Togo; Tel: +228 90028868, +228 985630oo; Email: folyvon@gmail.com Received date: 24 September 2021; Accepted date: 18 October 2021; Published date: 26 October 2021

Citation: Agbeko F, Dossou FC, Fiawoo M, Takassi EO, Kato MK, Guédénon MK, Segbedji KAR, Akolly DAE, N'Zonou M, Talboussouma S, Pakoudjare M, Batalia HD, Abalo KE, Djadou EK, Douti KN, Gbadoe AD, Atakouma YD, Gnamey DK. Congenital Constriction Band Syndrome: Clinical Study of Three Cases in Togo. Asp Biomed Clin Case Rep. 2021 Oct 26;4(3):170-78.

Copyright (C) 2021 Agbeko F, Dossou FC, Fiawoo M, Takassi EO, Kato MK, Guédénon MK, Segbedji KAR, Akolly DAE, N'Zonou M, Talboussouma S, Pakoudjare M, Batalia HD, Abalo KE, Djadou EK, Douti KN, Gbadoe AD, Atakouma YD, Gnamey DK. This is an open-access article distributed under the Creative Commons Attribution License, which permits unrestricted use, distribution, and reproduction in any medium provided the original work is properly cited.

\section{Abstract}

Introduction: Congenital constriction band syndrome (CCBS) or amniotic band syndrome is a complex set of congenital malformations, mainly affecting the limbs, but also the craniofacial and thoraco-abdominal region.

The Patients: The purpose of this work is to describe the clinical and diagnostic aspects of CCBS in Togo in relation to 03 clinical cases.

The Primary Diagnoses, Interventions, and Outcomes: The first case is characterized by an asymmetric bilateral superficial constriction groove of the lower limbs, pseudosyndactylias and synostosis of the tibia and fibula on X-ray. The second has a deep strangulation in the left arm with an amputation of the fingers associated with hypochromic skin lesions, poorly hemmed polylobal ear and skin growths. The latter characterized by persistent bridle, strangulation and ischemia downstream of that of the left wrist with postnatal amputation of the left hand.

Conclusion: The strengthening of antenatal diagnosis, the introduction of genetic counselling and the establishment of a national malformations register should make it possible to improve the management of cases of amniotic flange disease.

\section{Keywords}

Amniotic Band Syndrome, Constriction Ring, Limb Congenital Malformation, Togo 
Citation: Agbeko F, Dossou FC, Fiawoo M, Takassi EO, Kato MK, Guédénon MK, Segbedji KAR, Akolly DAE, N’Zonou M, Talboussouma S, Pakoudjare M, Batalia HD, Abalo KE, Djadou EK, Douti KN, Gbadoe AD, Atakouma YD, Gnamey DK. Congenital Constriction Band Syndrome: Clinical Study of Three Cases in Togo. Asp Biomed Clin Case Rep. 2021 Oct 26;4(3):170-78.

\section{Case Series}

\section{Abbreviations}

CCBS: Congenital Constriction Band Syndrome; ABD: Amniotic Band Disease

\section{Introduction}

Congenital constriction band syndrome (CCBS) or amniotic band disease (ABD) is a group of complex congenital malformations, mainly involving the limbs, but also the craniofacial region and the thoracoabdominal axis [1]. It includes a group of lesions whose appearance seems to result from the ligation or compression of normal fetal structures: stricture grooves, amputations, pseudosyndactylies, atypical facial clefts, exencephaly. The flanges, more or less epithelialised fibrous filaments, may be in contact with the CCBS lesions, the annexes (placenta, amnion), or connected to each other. This is why they are referred to as amniotic bridges [2].

CCBS is rare, with an incidence of $1 / 1200$ to $1 / 15000$ live births [3]. In Africa, its incidence is not known, and the cases reported are from hospital data [4-8]. The flange is thus recognised as the cause of CCBS lesions by some, whereas for others it is a simple symptom, comparable to a postoperative intraperitoneal flange. Many authors [2], based on clinical findings and/or results of animal experiments, have developed different theories: endogenous, exogenous, vascular or genetic. None of these has yet been formally proven in humans.

Among the risk factors found, authors have reported a high rate of CCBS in populations living at high altitude, in stillbirths, in cases of a maternal history of acute fever, drug use or first trimester haemorrhage [6]. Early and accurate antenatal diagnosis is the key element of pre- and perinatal management and could sometimes make in utero surgery possible [9]. This diagnosis, increasingly made before birth, leaves the family in great distress [9]. Surgical treatments improve morphology, but only improve function if the constructed elements are integrated by the child into its body schema. Interventions should be undertaken very early: as an emergency at birth if there is a vascular disorder, or early if deformities are aggravated by rapid growth [10]. Attempts at in utero surgery by fetoscopy have been made but there is the problem of the indication of a technique that is still recent and not without risks, in the treatment of a condition whose functional prognosis is generally good [2]. We report a series of three observations on CCBS discovered in three different regions of Togo.

\section{Case Report $\mathrm{N}^{\circ} \mathbf{1}$}

\section{Patient Information:}

This is a ten-day-old female infant referred to the paediatric ward of the Centre Hospitalier Universitaire Sylvanus Olympio (CHU SO) in Lomé in 2015 for evaluation of his malformations. He was the first child of non-consanguineous parents. The father was 25 years old and the mother 20 years old. The pregnancy was carried to term without incident. No obstetric ultrasound was performed. There was no notion of fever during the pregnancy, nor the use of alcohol, tobacco or any toxic product during the pregnancy. Delivery was by vaginal delivery. The birth weight was $2700 \mathrm{~g}$, the height was $50 \mathrm{~cm}$ and the head circumference was $35 \mathrm{~cm}$.

\section{Clinical Findings:}

On entry examination, the following was noted: i) on the lower limbs, a circular constrictive depression in the thigh on the left (Fig-1) and on the right, a constriction in the lower leg and a second incomplete constriction (instep) (Fig-2); ii) in the upper limbs, presence of three well-formed fingers (I, III, IV) on the right with clinodactyly of IV, and syndactyly of the last phalanges of II and III; and ulnar clinodactyly of I and on the left hand, a central block of II-III and IV (Fig-3).

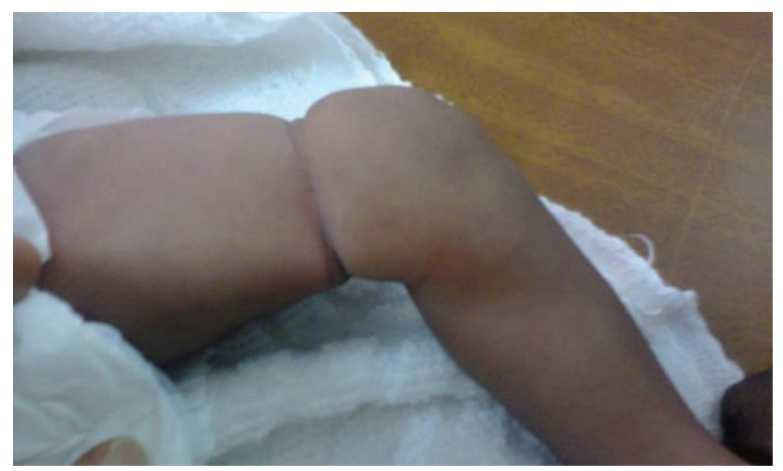

Fig-1: Ring constriction above the left knee. 
Citation: Agbeko F, Dossou FC, Fiawoo M, Takassi EO, Kato MK, Guédénon MK, Segbedji KAR, Akolly DAE, N’Zonou M, Talboussouma S, Pakoudjare M, Batalia HD, Abalo KE, Djadou EK, Douti KN, Gbadoe AD, Atakouma YD, Gnamey DK. Congenital Constriction Band Syndrome: Clinical Study of Three Cases in Togo. Asp Biomed Clin Case Rep. 2021 Oct 26;4(3):170-78.

\section{Case Series}

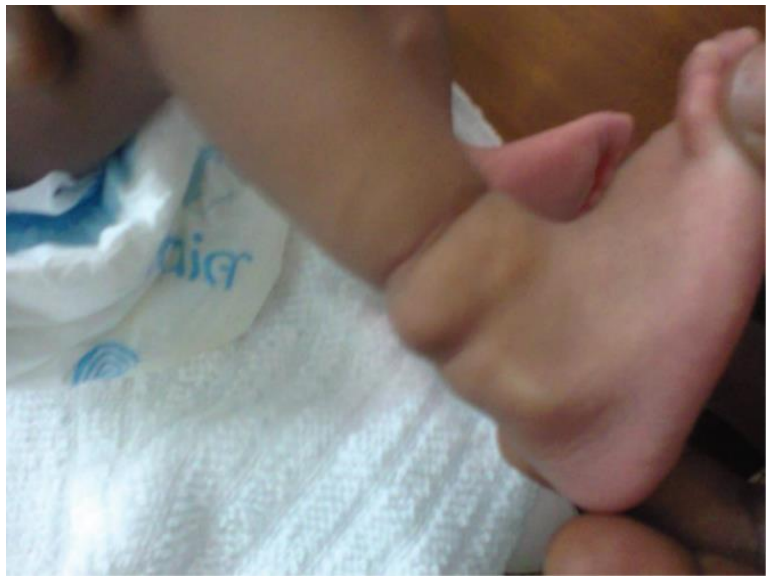

Fig-2: Circular constrictions in the lower right leg, one of which is incomplete.

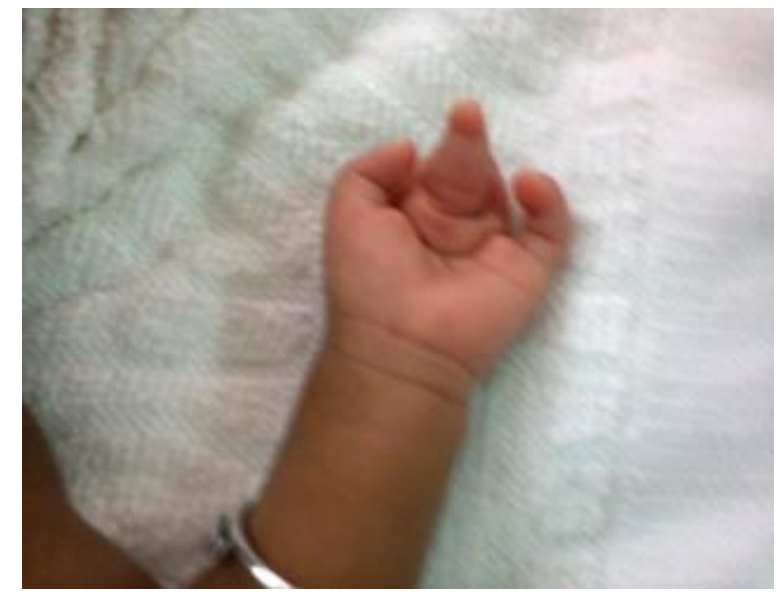

Fig-3: Central block of II-III and IV in the left hand.

\section{Diagnostic Assessment:}

Radiography revealed: i) in the right hand (Fig-4),

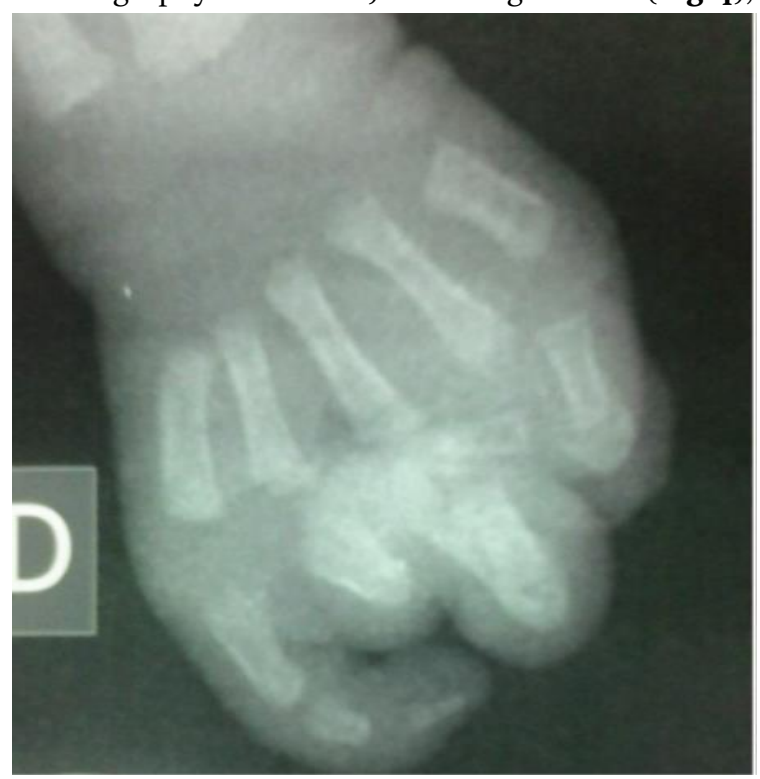

Fig-4: X-ray of the right hand

agenesis of the medial and distal phalanges of II and IV and fusion of the proximal phalanges of II, III and IV. ii) in the left hand (Fig-5), agenesis of the distal

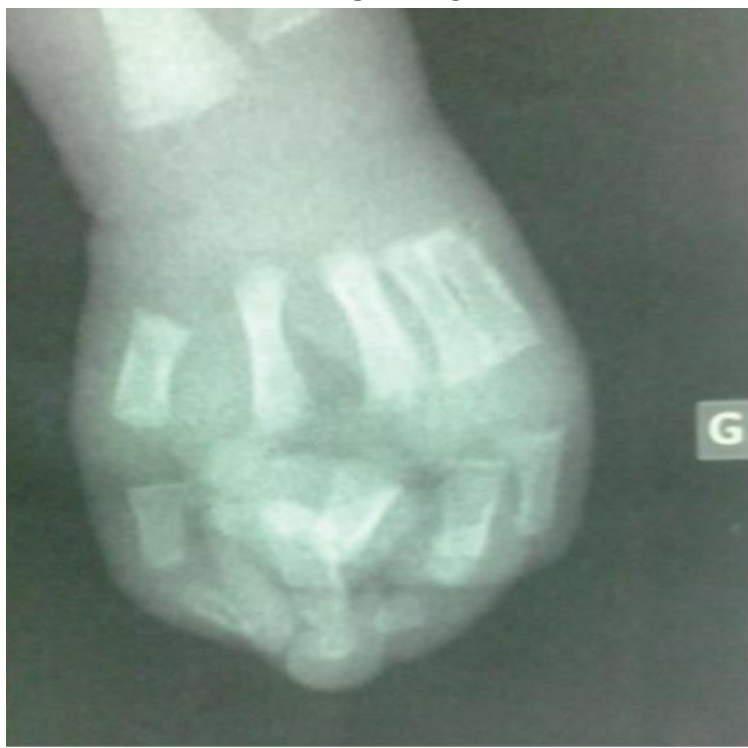

Fig-5: X-ray of the left hand

phalanges of III, IV and V, of the second phalanx of V and syndactyly of the proximal phalanges of II and III and of the fourth and fifth metacarpals ii) in the left leg (Fig-6), synostosis of the tibia and the fibula.

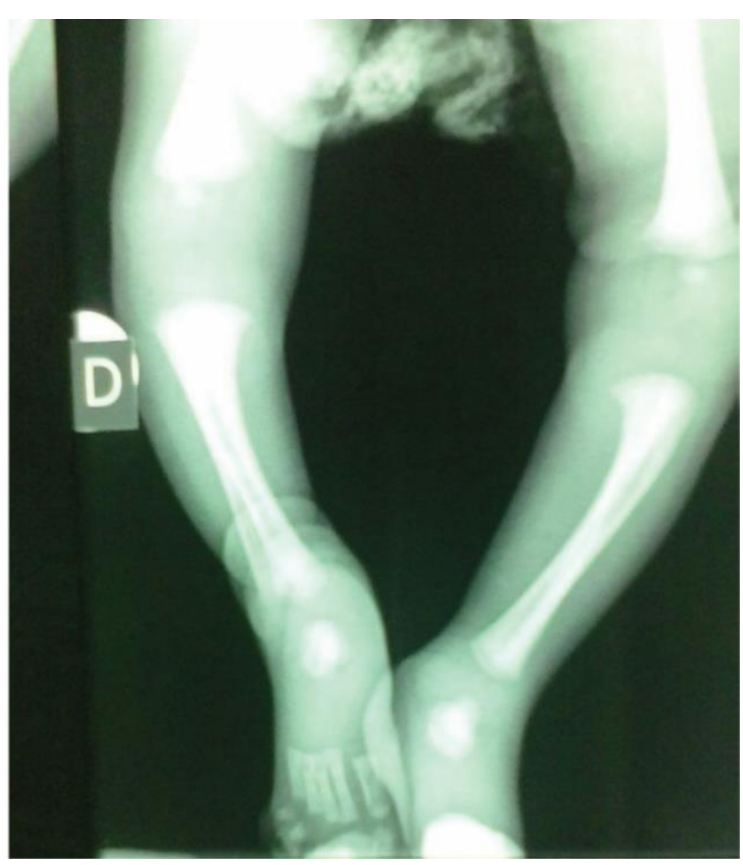

Fig-6: X-ray of the lower limbs

Constrictive bands and complex abnormalities of the bony structures of the extremities are suggestive of Adam complex syndrome.

\section{Therapeutic Intervention:}

No surgical treatment was performed. 
Citation: Agbeko F, Dossou FC, Fiawoo M, Takassi EO, Kato MK, Guédénon MK, Segbedji KAR, Akolly DAE, N’Zonou M, Talboussouma S, Pakoudjare M, Batalia HD, Abalo KE, Djadou EK, Douti KN, Gbadoe AD, Atakouma YD, Gnamey DK. Congenital Constriction Band Syndrome: Clinical Study of Three Cases in Togo. Asp Biomed Clin Case Rep. 2021 Oct 26;4(3):170-78.

\section{Case Series}

\section{Follow-up and Outcomes:}

The patient was lost to follow-up.

\section{Case Report $\mathrm{N}^{\circ} \mathbf{2}$}

\section{Patient Information:}

The second child was born to a 34-year-old mother, a trader living in Sokodé. He is the second of two children, of whom the 2-year-old sister was alive and in apparent good health. The father and mother were alive and in apparent good health. There was no notion of consanguinity, nor any known family defect. The mother had been on progestin-only contraceptives (Depo-provera) for two (02) years, but had missed an injection, hence the pregnancy. The pregnancy was regularly monitored in a medical-surgical centre in Sokodé from the $13^{\text {th }}$ week of amenorrhea (SA). An obstetrical ultrasound was carried out at the 2oth week of amenorrhoea, without any notable anomaly. The pregnancy was carried to term without incident. The delivery was done in the said centre by vaginal delivery of a male neonate, Apgar 9-10-10. The newborn had a birth weight of $2700 \mathrm{~g}$, height of 48 $\mathrm{cm}$, head circumference of $33 \mathrm{~cm}$. He was put to the breast within one hour of delivery.

\section{Clinical Findings:}

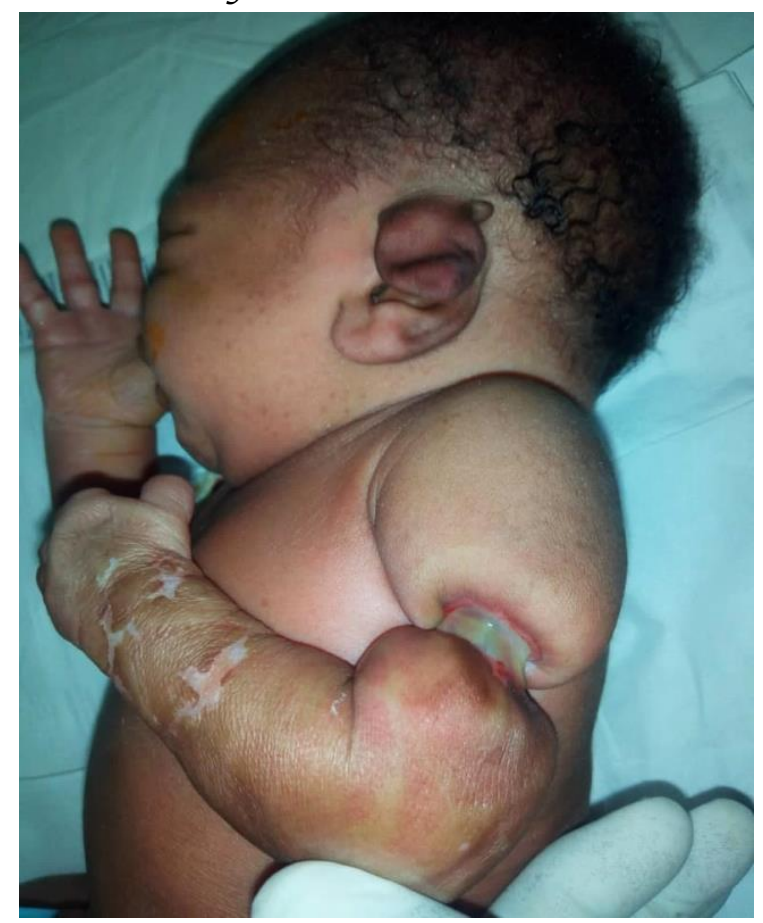

Fig-7: Deep circular constrictive depression exposing the bone on the left arm with hypochromic skin lesions on the left forearm and poorly hemmed polylobed left ear.
The newborn was referred to the paediatric department of the Sokodé Regional Hospital for a complex polymalformative syndrome on day 2 . On the left upper limb, there was a deep circular constrictive depression exposing the bone in the arm (Fig-7), adactyly of the second to fifth fingers of the left hand giving the appearance of amputated fingers and hypochromic skin lesions were observed on the forearm (Fig-8). The left ear was poly-lobed and poorly hemmed (Fig-7). There were growths on the head (one thick growth of about $5 \mathrm{~cm}$ ) and on the back (two single-rooted growths of about $7 \mathrm{~cm}$ ).

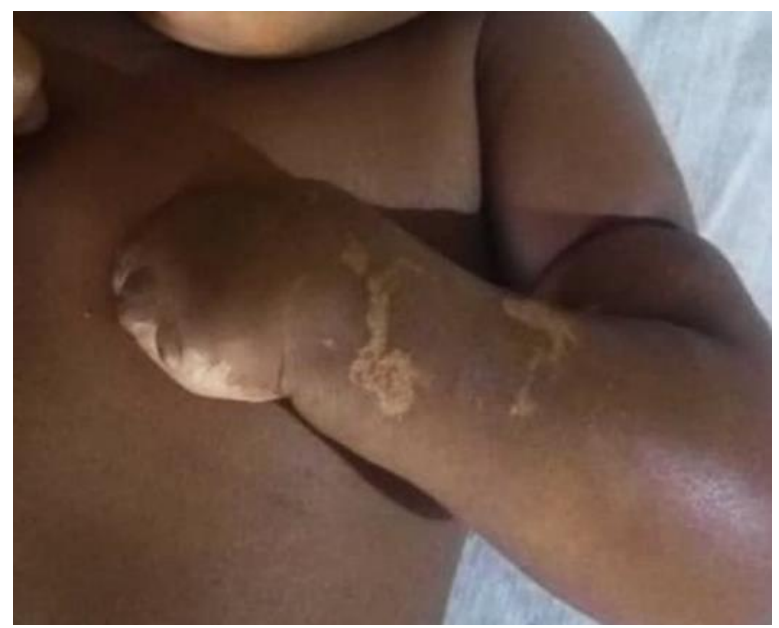

Fig-8: Adactyly of the second to fifth fingers of the left hand giving the appearance of amputated fingers with hypochromic skin lesions on the left forearm.

\section{Diagnostic Assessment:}

The left upper limb showed a radiographic appearance of a soft tissue sheathing flange without impact on the humerus (Fig-9).

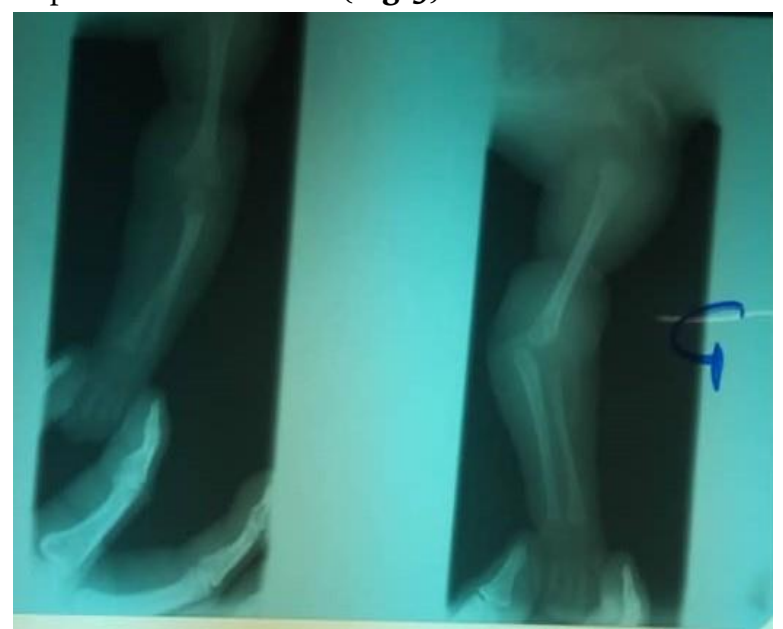

Fig-9: X-ray of the left upper limb (front and side views). 
Citation: Agbeko F, Dossou FC, Fiawoo M, Takassi EO, Kato MK, Guédénon MK, Segbedji KAR, Akolly DAE, N’Zonou M, Talboussouma S, Pakoudjare M, Batalia HD, Abalo KE, Djadou EK, Douti KN, Gbadoe AD, Atakouma YD, Gnamey DK. Congenital Constriction Band Syndrome: Clinical Study of Three Cases in Togo. Asp Biomed Clin Case Rep. 2021 Oct 26;4(3):170-78.

\section{Case Series}

\section{Therapeutic Intervention:}

He benefited from newborn care (vitamin K1, cord care, rifamicin eye drops, etc.). Following the treatment, after a surgical opinion, the newborn was transferred to the surgical department of the CHR-S where he underwent a plasty on D7 (raphie of the muscles of the left arm, removal of the excrescences, etc.).

\section{Follow-up and Outcomes:}

On discharge from the surgical intensive care unit at D11, the newborn was readmitted to paediatrics. After examination and continued care (dressings, analgesics and antibiotics), his discharge was decided at D23.

\section{Case Report $\mathrm{N}^{\circ} \mathbf{3}$}

\section{Patient Information:}

The newborn female child is born to a 29-year-old mother living near Anié, in the Plateaux region. He is the last child of four siblings, all of whom are alive and in apparent good health, as are both parents. There was no notion of consanguinity, nor any known family defect. The mother underwent 3 prenatal consultations at the Nyamassila hospital where no pathology was detected and prenatal care was administered normally. But the pregnancy check-up was not honoured, in particular the obstetrical ultrasound. The pregnancy was carried to term without incident. The delivery was done at Nyamassila hospital by vaginal delivery, Apgar 9-10-10, weight $2900 \mathrm{~g}$, height $49 \mathrm{~cm}$ and $\mathrm{PC} 33 \mathrm{~cm}$.
He was put to the breast within one hour of delivery.

\section{Clinical Findings:}

Somatic examination on the first day of life showed a skin constriction groove on the left upper limb with postnatal persistence of the fibrous flange at the level of the constriction zone on the arm (Fig-10A), a circular constriction groove on the wrist and skin necrosis on the hand up to the constriction groove on the wrist (Fig-10B).

\section{Diagnostic Assessment:}

The radiological findings at 4 months of life in the left upper limb are a radiographic appearance of a soft tissue flange in the left arm without impact on the humerus and an amputation of the left hand with radio-ulnar hypoplasia (Fig-11).

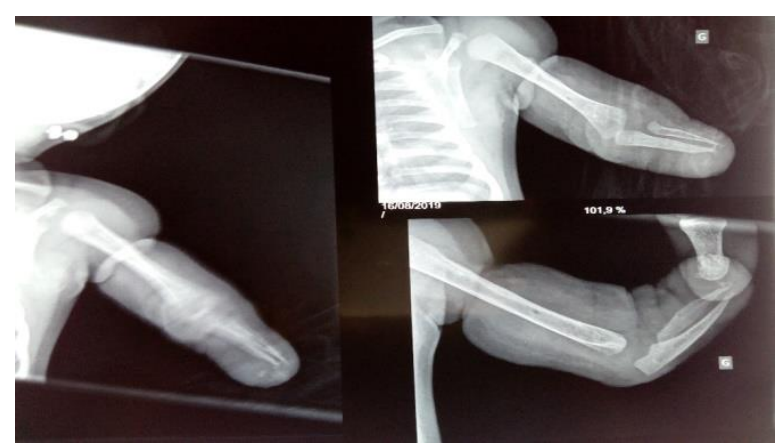

Fig-11: X-ray of the left lower limb at 4 months of age, front and side view: soft tissue flange without impact on the humerus and a left hand amputation with radioulnar hypoplasia.
A)

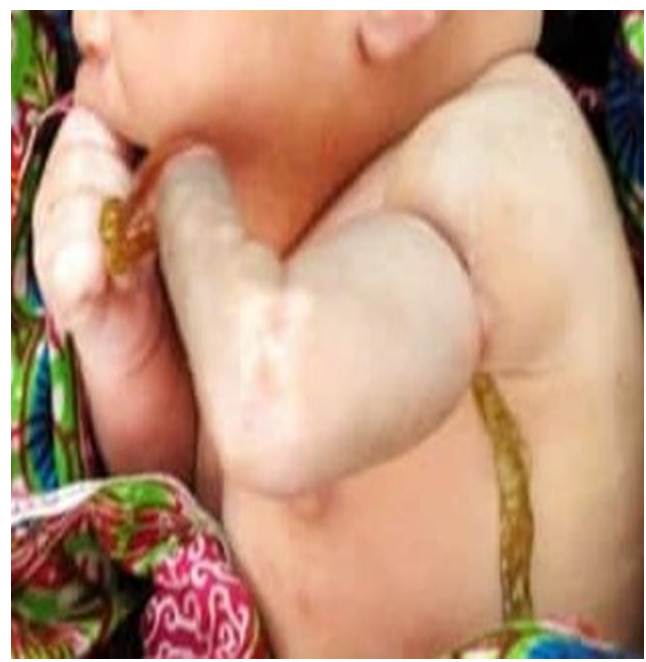

B)

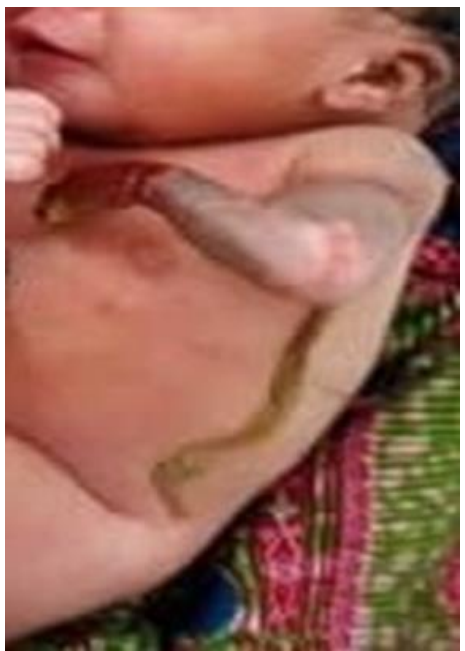

Fig-10:

A: Skin constriction groove with persistence of the fibrous flange at the constriction zone

B: skin necrosis of the left hand up to the wrist constriction groove and the amniotic flange. 
Citation: Agbeko F, Dossou FC, Fiawoo M, Takassi EO, Kato MK, Guédénon MK, Segbedji KAR, Akolly DAE, N’Zonou M, Talboussouma S, Pakoudjare M, Batalia HD, Abalo KE, Djadou EK, Douti KN, Gbadoe AD, Atakouma YD, Gnamey DK. Congenital Constriction Band Syndrome: Clinical Study of Three Cases in Togo. Asp Biomed Clin Case Rep. 2021 Oct 26;4(3):170-78.

\section{Case Series}

\section{Therapeutic Intervention:}

At birth, after having benefited from newborn care (vitamin K1, cord care, rifamicin eye drops, etc.), he was referred to the regional hospital of Atakpamé for a complex polymalformative syndrome. Due to lack of financial means, the newborn was taken home without surgical care.

\section{Follow-up and Outcomes:}

The examination at 2 months 14 days of age showed the persistence of the constriction groove in the left arm without amniotic bridges and an amputation of the left hand (spontaneous according to the parents after one month of life) (Fig-12).

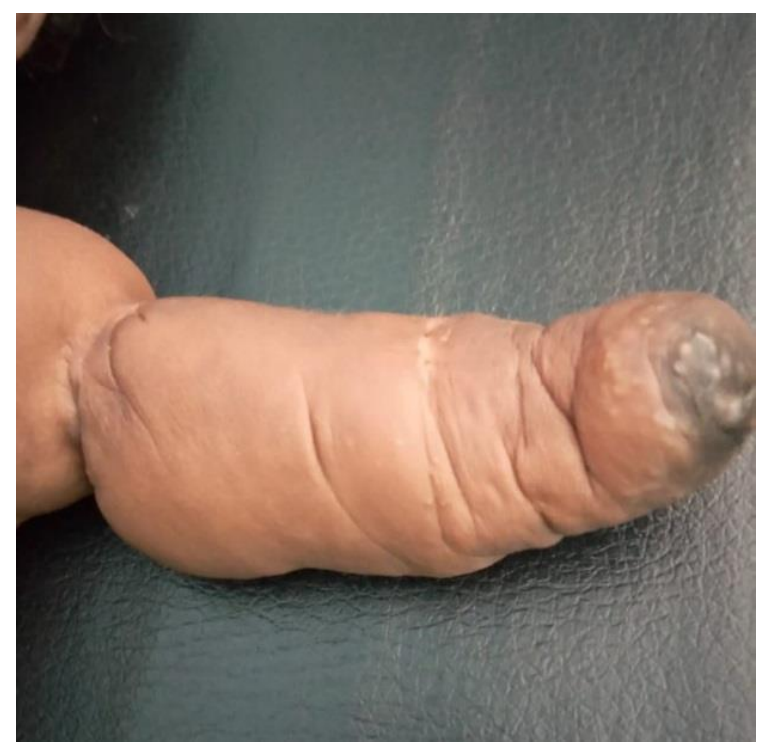

Fig-12: Spontaneous postnatal amputation of the left hand.

\section{Discussion}

Congenital constriction band syndrome (CCBS) or Amniotic band syndrome is a well-described clinical entity, which includes several congenital deformities [9]. Hand malformations and limb defects represent the most frequent clinical characteristics, gathering, with variable localization, constriction rings, acrosyndactylies and amniotic amputations [9]. Limb Body Wall Complex (LBWC) is a malformative complex characterised by severe, multiple and fatal congenital anomalies of the fetus, with exencephaly and/or encephalocele, severe anterior parietal malformations and limb malformations, with or without facial clefts [6]. In Togo, the cases of CCBS that we report are the first to our knowledge. In another African study in
Burkina Faso, Nagalo et al. described in 2015 a series of five cases of CCBS [4].

The diagnosis of CCBS is possible as early as the first trimester of pregnancy, depending on the nature and severity of the malformations observed. Obstetric ultrasound is not always available to all pregnant women as in observation 1 and 3. Even when ultrasound is available, technical (poor performance of the equipment) and/or human (inexperience of the sonographer and lack of knowledge of malformations) factors may limit antenatal diagnosis. In the majority of cases, a gestational or neonatal pathological history is found on questioning [11]. In our series, the gestational history was marked by the use of injectable contraceptives with only progestin (Depo-provera) in Sokodé as in 73 and the infectious origin (malaria) in Nyamassila. Abdominal trauma [3], amniocentesis, toxic products (cocaine), polymedication [12], epidermolysis bullosa, uterine malformations and infectious origin are evoked. All these factors support the mechanical theory of amniotic rupture proposed by Torpin, which is widely accepted, although not formally proven [13]. The diagnosis was made at birth in the three Togolese cases, contrary to an age of discovery varying from 6 to 8 months in the literature [14]. This finding could be explained by the presence of other visible malformations in our study. No familial cases were reported. It is accepted by some authors that CCBS does not carry a risk of familial transmission, except in the rare cases where it occurs in the context of an inherited connective tissue disease $[10,15]$. Karyotyping is unnecessary in this condition as it always returns normal [5]. However, it seems justified in case of diagnostic doubt.

CCBS is a syndrome associating multiple polymorphic and asymmetric malformations, not respecting any embryonic systematisation [16]. The severity of these malformations, which are often incompatible with life, is very variable [3]. Those of the upper and lower extremities are the most common and consist of asymmetrical skin strictures, distal atrophy, congenital intrauterine amputations, acrosyndactyly and lymphoedema [9]. The association with other anomalies, such as club feet or cleft lip and palate, has been described [4]. Limb deformities are 
Citation: Agbeko F, Dossou FC, Fiawoo M, Takassi EO, Kato MK, Guédénon MK, Segbedji KAR, Akolly DAE, N'Zonou M, Talboussouma S, Pakoudjare M, Batalia HD, Abalo KE, Djadou EK, Douti KN, Gbadoe AD, Atakouma YD, Gnamey DK. Congenital Constriction Band Syndrome: Clinical Study of Three Cases in Togo. Asp Biomed Clin Case Rep. 2021 Oct 26;4(3):170-78.

Case Series

found in $65 \%$ of cases, and facial deformities are present in $48 \%$ of cases [3]. In our study, bilateral lower limb and unilateral upper limb involvement was found. The grooves in our study are located in the arm (observation 2 and 3), the thigh and the neck of the foot (observation 1). A German study reported a rare case of a skin constriction groove surrounding the entire abdominal circumference and involving the umbilicus, this feature has only been reported in 10 cases in the literature [17]. The depth of the groove and its circumferential extension are variable, determining more or less important compressive phenomena on the underlying elements: vessels, nerves, muscles, tendons, periosteum and bones. In our series, all the grooves were located in the limbs, one groove was deep (observation 2) and 02 were superficial. The impact of the grooves on the soft tissue can be divided into four parts: arterial compression, venous and lymphatic compression, nerve and tendon compression, and bone deformities. Arterial compression ischemia is not encountered at birth. Indeed, in the case of reduced arterial flow, amputations are completed before birth and the newborn presents with a so-called primary amputation [5]. However, it is possible to have a limb that is still persistent but ischaemic at birth, as we have seen in one of our patients (observation 3).

In a prospective South African study [18], the arterial vasculature of the affected limbs was examined using magnetic resonance angiography (MRA) and CT angiography. This study concluded that congenital vascular anomalies were present in $60 \%$ of cases. Furrow depth was an important factor as patients with deep stricture furrows and those with primary amputation had $100 \%$ vascular anomalies compared to $11.1 \%$ for those with superficial furrows. In our series, one spontaneous amputation after birth was performed (observation 3). The occurrence of lymphoedema downstream of a limb constriction is a sign of vascular repercussions with compression of venous and lymphatic structures. It leads to fears of reduced vascular perfusion in the distal segment, the outcome of this process being amputation in utero [17]. In a Moroccan study [5], three cases of lymphoedema were reported out of 24 cases, in contrast to the Togo cases. Nerve and tendon compression is rare ([14] compression of both ulnar and median nerves; [19] painless superinfected lesions in the foot). In our series, no patient showed signs of nerve and tendon compression. This may be related to the age of discovery of the disease (at birth) [5]. Concerning bone deformations, the musculoskeletal growth of the fetal limb may be restricted, giving, depending on the severity of the constriction, an angular deformity, thinning of the cortical bone, thinning of the medullary canal, up to the solution of bone continuity, realising a congenital pseudoarthrosis $[10,20]$. In our series, there was one case of synostosis of the tibia and fibula, with the sulcus in the thigh (observation 1).

Two cases of in utero finger amputations (observation 1 and 2) were observed in our study, 01 case of postnatal amputation (observation 3) and 01 case of syndactyly. According to Byrne [21], amniotic amputations as well as acrosyndactyly are among the distal malformations that occur in $50 \%$ of cases in CCBS. Metacarpal hypoplasia has also been described in 30\% of amputated hands [22]. In our series, we found an association with hypochromic skin lesions [4], poorly hemmed polylobed ear and skin growths in Sokodé (observation 2).

Therapeutically, management only concerns isolated or associated anomalies that only affect the functional prognosis of one or more extremities (constriction grooves, pseudo-syndactyly, club feet) [5]. Severe craniofacial and visceral polymalformations are generally incompatible with life and inaccessible to any therapeutic option [7]. If left untreated, constrictive skin folds and pseudo-syndactyly are irreversible, but do not worsen after birth [5]. When constrictive furrows are responsible for vascular repercussions with the presence of lymphoedema and venous stasis, excision with release of the vascular-nervous pedicle is urgent and carried out in the first 48 hours of life [5]. In circumferential constrictive grooves, some authors recommend a two-stage procedure, in order not to aggravate the vascular disorders. In order to prevent recurrence of the initial constriction, it is necessary to modify the path of the scar with Z or W skin flaps [10]. Pseudo-syndactyly should be released early, during the neonatal period, to limit the progression to 
Citation: Agbeko F, Dossou FC, Fiawoo M, Takassi EO, Kato MK, Guédénon MK, Segbedji KAR, Akolly DAE, N’Zonou M, Talboussouma S, Pakoudjare M, Batalia HD, Abalo KE, Djadou EK, Douti KN, Gbadoe AD, Atakouma YD, Gnamey DK. Congenital Constriction Band Syndrome: Clinical Study of Three Cases in Togo. Asp Biomed Clin Case Rep. 2021 Oct 26;4(3):170-78.

Case Series

camptodactyly. When the tips of the two fingers are joined by a simple membrane, this can be simply excised and sutured. In the case of more extensive fusions, it is necessary to dissect the soft tissue and perform a skin graft to avoid adhesions during healing [10]. In the case of digital amputation, a secondary release can be performed to give maximum length to the amputated fingers [20]. Observation 2 benefited from a plasty (raphie of the muscles of the left arm, removal of the excrescences, etc.).

The obstetrical prognosis of patients with a fetus with a CCBS-related anomaly is not altered compared to the general population [3]. However, some authors report an increased rate of late miscarriage and prematurity in cases of SBC [23]. The prognosis of surviving children is variable and depends on the severity of the foetal lesions (craniofacial malformations leading to motor, behavioural and cognitive disorders). A medical termination of pregnancy may be proposed when these fetal anomalies are recognised as being incompatible with life or responsible for a severe handicap, and being beyond any therapeutic resources (which excludes limb amputations). In Africa, termination of pregnancy is still hardly granted by the ethics committee and also hardly accepted by patients for socio-cultural and religious reasons. In our series, the prognosis of the managed CCBS case seems excellent (observation 2). A multidisciplinary management of the pregnancy, involving obstetricians, pediatricians, plastic and pediatric surgeons, radiologists, is essential in order to explain to the couple the difficulty of establishing a functional prognosis in the ante-natal period, as well as the postnatal or even prenatal therapeutic possibilities impossible in our environment.

\section{Conclusion}

CCBS is a rare condition in our facility. Infants with congenital constriction ring deformities should be referred for surgery early. A multidisciplinary team should be implemented in Togo.

\section{Acknowledgements}

We acknowledge Docteur Kato Kossi Mawulolo, Docteur Fidèle Comlan Dossou and Professor Koffi Didier Gnamey.

\section{Funding}

This research did not receive any specific grant from funding agencies in the public, commercial, or not-for profit sectors.

\section{Ethics Approval and Consent to Participate}

This study was approved by the ethics committee of Togo (Ref Nº16/2018/PED/MSHP), Lomé, Togo.

\section{Consent for Publication}

We obtained consent from parents of the newborns examined in the study. For the respondents, the objectives and benefits of participating in the survey and its conduct were clearly stated, as well as his right to interrupt the interview without justification. An informed consent form signed after the verbal explanation was made by the investigating officer in the language understood by the parents. A copy of the written consent is available for review by the Editor inChief of this journal.

\section{Availability of Data and Materials}

"Data sharing not applicable to this article as no datasets were generated or analysed during the current study".

\section{Competing Interests}

The authors declare that they have no competing interests. The authors have no association with financial or non-financial organizations.

\section{References}

[1] Sentilhes L, Verspyck E, Patrier S, Eurin D, Lechevallier J, Marpeau L. Maladie des brides amniotiques: étiopathogénie, diagnostic anténatal et prise en charge néonatale [Amniotic band syndrome: pathogenesis, prenatal diagnosis and neonatal management]. J Gynecol Obstet Biol Reprod (Paris). 2003 Dec;32(8 Pt 1):693-704. French. [PMID: 15067893]

[2] Mézel A, Manouvrier S. Maladie des brides amniotiques. EM Consulte; 8 Mar 2011 [cited on 3 Sept 2019]. Available from : https://www.emconsulte.com/en/article/283209

[3] Seeds JW, Cefalo RC, Herbert WN. Amniotic band syndrome. Am J Obstet Gynecol. 1982 Oct 
Citation: Agbeko F, Dossou FC, Fiawoo M, Takassi EO, Kato MK, Guédénon MK, Segbedji KAR, Akolly DAE, N'Zonou M, Talboussouma S, Pakoudjare M, Batalia HD, Abalo KE, Djadou EK, Douti KN, Gbadoe AD, Atakouma YD, Gnamey DK. Congenital Constriction Band Syndrome: Clinical Study of Three Cases in Togo. Asp Biomed Clin Case Rep. 2021 Oct 26;4(3):170-78.

\section{Case Series}

1;144(3):243-48. [PMID: 7124837]

[4] Nagalo K, Badiel R, Kouéta F, Tall FH, Yé D. Le syndrome des brides amniotiques et ses difficultés diagnostiques et de prise en charge au Burkina Faso [Amniotic bands syndrome and its diagnostic difficulties and management in Burkina Faso]. Pan Afr Med J. 2015 Mar 6;20:208. French. [PMID: 26113939]

[5] Hilali A. La maladie des brides amniotiques aspects orthopédiques et thérapeutiques: à propos d'une série de 24 cas. Université Mohammed; 2013 [cited on 3 Sept 2019]. Available from:

http://ao.um5.ac.ma/xmlui/handle/123456789/166

[6] Seddiki AE, Benameur S, Merzgioui SE, Agouni I, Messaoudi S, Amrani R. La maladie des brides amniotiques: à propos d'une observation. Rev Médecine Périnatale [Amniotic Band Syndrome: About one Observation]. 2018;10(2):120-24. French.

[7] Adadi H, Chaara H, Attar I, Jayi S, Alaoui FF, Melhouf MA. Maladie des brides amniotiques: diagnostic anténatal et difficultés de prise en charge (à propos de 02 cas de malformations létales) [Amniotic band syndrome: prenatal diagnosis and management challenges (about 2 cases of lethal malformations)]. Pan Afr Med J. 2019 Mar 13;32:116. French. [PMID: 31223406]

[8] Ozinko MO, Otei OO, Ekpo RG, Ebri OI. Congenital Constriction Band Syndrome: A Case Report and Literature Review. Saudi J Med. 2017;2(5):93-97.

[9] Poeuf B, Samson P, Magalon G. Syndrome des brides amniotiques [Amniotic band syndrome]. Chir Main. 2008 Dec;27 Suppl 1:S136-47. French. [PMID: 18948051]

[10] PATTERSON TJ. Congenital ring-constrictions. Br J Plast Surg. 1961 Apr;14:1-31. [PMID: 13733379]

[11] Strauss A, Hasbargen U, Paek B, Bauerfeind I, Hepp H. Intra-uterine fetal demise caused by amniotic band syndrome after standard amniocentesis. Fetal Diagn Ther. 2000 Jan-Feb;15(1):4-7. [PMID: 10705208]

[12] Sinha R, Singh B, Kiran YK, Singh D, Raman TsR. Amniotic Band Disruption Sequence. Med J Armed Forces India. 2009 Jul;65(3):274-75. [PMID: 27408266]
[13] Warkany J. Fetal Malformations Caused by Amnion Rupture During Gestation, by Richard Torpin, M.D. Springfield, Illinois: Charles C Thomas, 1968, 165 pp. Pediatrics. 1969 Mar;43(3):478.

[14] Beidas O, Rayan GM, Al-Harthy A. Digital sucking induced trophic ulcers caused by nerve deficit from amniotic constriction band. J Plast Reconstr Aesthet Surg. 2010 Aug;63(8):e631-34. [PMID: 20347623]

[15] Khan F, Shah SA, Khan N, Ullah F. Pattern of constriction band syndrome. Rawal Med J. 2010;35(2):184-87.

[16] Mahony BS, Filly RA, Callen PW, Golbus MS. The amniotic band syndrome: antenatal sonographic diagnosis and potential pitfalls. Am J Obstet Gynecol. 1985 May 1;152(1):63-68. [PMID: 3887927]

[17] Evans MI. Amniotic bands. Ultrasound Obstet Gynecol. 1997 Nov;10(5):307-18. [PMID: 9444041]

[18] Daya M, Makakole M. Congenital vascular anomalies in amniotic band syndrome of the limbs. J Pediatr Surg. 2011 Mar;46(3):507-13. [PMID: 21376201]

[19] Barenberg LH, Greenberg B. Intrauterine amputations and constriction bands: report of a case with anesthesia below the constriction. Am J Dis Child. 1942;64(1):87-92.

[20] Bouché-Pillon MA, Lefort G, Daoud S. Maladie amniotique. A propos d'une série de 20 cas [Amniotic disease. Apropos of a series of 20 cases]. Chir Pediatr. 1987;28(4-5):235-9. French. [PMID: 3442929]

[21] Byrne J, Blanc WA, Baker D. Amniotic band syndrome in early fetal life. Birth Defects Orig Artic Ser. 1982;18(3B):43-58. [PMID: 7188597]

[22] Satake H, Ogino T, Iba K, Watanabe T, Eto J. Metacarpal hypoplasia associated with congenital constriction band syndrome. J Hand Surg Am. 2012 Apr;37(4):76o-63. [PMID: 22397842]

[23] Torpin R. Amniochorionic Mesoblastic Fibrous Strings and Amnionic Bands: Associated Constricting Fetal Malformations or Fetal Death. Am J Obstet Gynecol. 1965 Jan 1;91:65-75. [PMID: 14245093] 